\title{
Measurement of Nine Human Milk Proteins by Nephelometric Immunoassays: Application to the Determination of Mature Milk Protein Profile
}

\author{
PAUL M. MONTAGNE, VIRGINIE S. TRÉGOAT, MARIE L. CUILLIĖRE, MARIE C. BÉNÉ, \\ and GILBERT C. FAURE
}

\author{
GRIP, Immunology Laboratory, Faculty of Medicine, Nancy, France
}

\begin{abstract}
Objectives: Microparticle-enhanced nephelometric immunoassays for six human milk proteins ( $\beta$-casein, $\kappa$-casein, $\alpha$-lactalbumin, serum albumin, lactoferrin, and lysozyme) and conventional immunonephelometry assays for immunoglobulin A, C3, and C4 complement proteins were developed and characterized.

Design and methods: Microparticle-enhanced nephelometric immunoassays are competitive assays based on the nephelometric quantification of the inhibition of microparticle-protein conjugates immunoagglutination by the proteins to be assayed.

Results: High precision (CVs ranged from 1\% to 14\% in within- and between-assays) and recovery (linear recovery in dilution-overloading assay) ensure a reliable determination of the main human milk proteins by single-step homogeneous nephelometric immunoassays, accurate over wide ranges of concentration. These immunoassays were easily applied to a large number of mature human milk samples (between 373 and 503 according to the proteins tested). Conclusions: The immunoassays developed could be applied to the fast determination of human milk protein profile usable for nursery milk bank and fortification. Copyright (C) 2000 The Canadian Society of Clinical Chemists
\end{abstract}

KEY WORDS: human milk; protein profile; lactation; immunoassay; nephelometry.

\section{Introduction}

B reast milk contains various components required by the neonate for its growth and development (1). Among these components, milk-specific and plasma proteins, such as beta-casein ( $\beta-\mathrm{CN})$, kappacasein $(\kappa-\mathrm{CN})$, alpha-lactalbumin ( $\alpha-\mathrm{LA})$, serum albumin (SA), lactoferrin (LF), lysozyme (LZ), immunoglobulins A (IgA), C3, and C4 complement fractions have important nutritious and immunological functions. Numerous methods, such as fast protein liquid chromatography $(2,3)$, polyacrylamide gel electrophoresis $(4,5)$, ion-exchange chromatography (6), enzyme activity measurement (7), and var-

Correspondence: Paul Montagne, Ph.D., Laboratoire d'Immunologie, Faculté de Médecine, BP 184, 54505 Vandoeuvre les Nancy Cedex, France. E-mail: paulmont@ grip.u-nancy.fr

Manuscript received November 2, 1999; revised January 3, 2000; accepted January 31, 2000. ious types of immunoassays (8-14), have been reported to assay these proteins in human milk. Most of these techniques lack sensitivity and moreover require sample pretreatment or long incubation periods. Their diversity often impedes an easy comparison of the results published by different authors.

Conventional immunonephelometry, based on the nephelometric quantification of the light scattered by antigen-antibody complexes formed during liquid-phase immunoprecipitation, is routinely used for the determination of human serum proteins, including IgA, C3, and C4 complement fractions (15). Our group had developed and published a series of microparticle-enhanced nephelometric immunoassays specially designed for the determination of $\beta-\mathrm{CN}$ (16), к-CN (17), $\alpha-\mathrm{LA}$ (18), SA, LF (19), and LZ (20) and applied conventional immunonephelometry to the assay of IgA, C3, and C4 (21) in human milk. Here we report a comparative description and analysis of these assays, demonstrating the feasability of a rapid and reliable determination of the concentration of the nine main proteins of human milk. This technically homogeneous approach leads to the assessment of a protein profile of mature human milk.

\section{Methods}

\section{REAGENTS}

Purified human milk proteins (whole CN containing 71 and $13 \%$ of $\beta$ - and $\kappa-\mathrm{CN}$, respectively, $\alpha-\mathrm{LA}$, LZ, and LF) and SA, used for microparticle coating in the preparation of microparticle-protein conjugates and as standard in microparticle-enhanced nephelometric immunoassays were from Sigma Chemical Co. (St Louis, MO, USA). Purified immunoglobulin fractions of rabbit antihuman $\alpha$-LA, antihuman LF, and antihuman LZ antisera were obtained from Dako (Glostrup, Denmark). Anti-human SA, anti-human IgA ( $\alpha$-chains), and antihuman C3 (C3c) and C4 rabbit antisera, as well as human IgA, C3, and C4 standard were purchased from Behring 
TABLE 1

Procedures for Determination of Human Milk Beta-Casein ( $\beta-\mathrm{CN})$, Kappa-casein ( $\kappa-\mathrm{CN})$, Alpha-lactalbumin $(\alpha-\mathrm{LA})$, Serum Albumin (SA), Lactoferrin (LF), Lysozyme (LZ), Immunoglobulins A (IgA), C3, and C4 Complement Fractions

\begin{tabular}{|c|c|c|c|c|c|c|c|c|c|}
\hline Protein & $\beta-\mathrm{CN}$ & $\kappa-\mathrm{CN}$ & $\alpha-\mathrm{LA}$ & SA & $\mathrm{LF}$ & $\mathrm{LZ}$ & IgA & C3 & $\mathrm{C} 4$ \\
\hline \multicolumn{10}{|l|}{ Milk sample } \\
\hline Dilution & $1 / 600$ & $1 / 600$ & $1 / 15000$ & $1 / 600$ & $1 / 300$ & $1 / 600$ & $1 / 100^{\mathrm{a}}$ & $1 / 10^{\mathrm{a}}$ & $1 / 10^{\mathrm{a}}$ \\
\hline Volume $(\mu \mathrm{L})$ & 30 & 30 & 30 & 30 & 30 & 30 & 100 & 100 & 100 \\
\hline \multicolumn{10}{|l|}{ Antiserum } \\
\hline Dilution & $1 / 150$ & $1 / 80$ & $1 / 650$ & $1 / 125$ & $1 / 130$ & $1 / 90$ & $1 / 1$ & $1 / 1$ & $1 / 1$ \\
\hline Volume $(\mu \mathrm{L})$ & 30 & 30 & 30 & 30 & 30 & 30 & 40 & 40 & 40 \\
\hline \multicolumn{10}{|l|}{$\begin{array}{l}\text { Microparticle conjugate } \\
(30 \mu \mathrm{L})\end{array}$} \\
\hline Concentration $(\mathrm{g} / \mathrm{L})$ & 3.3 & 3.3 & 1.4 & 2.8 & 1.4 & 2.8 & & & \\
\hline \multicolumn{10}{|l|}{ Diluent } \\
\hline Composition & $\mathrm{NB}^{\mathrm{b}}$ & NB & NB & NB & NB & NB & $\mathrm{S}^{\mathrm{c}}$ & NB & NB \\
\hline Volume $(\mu \mathrm{L})$ & 210 & 210 & 210 & 210 & 210 & 210 & 160 & 160 & 160 \\
\hline Incubation time (min) & 60 & 30 & 60 & 60 & 30 & 60 & 30 & 30 & 30 \\
\hline Calibration range $(\mathrm{g} / \mathrm{L})$ & $0.6-18.3$ & $0.1-4.6$ & $0.5-16.9$ & $0.2-3.0$ & $0.7-21.6$ & $0.1-1.5$ & $0.2-6.2$ & $0.01-0.37$ & $0.01-0.29$ \\
\hline $\begin{array}{l}\text { Repeatability of } \\
\text { calibration }(\%)\end{array}$ & $1.1-3.0$ & $1.8-2.7$ & $2.0-6.3$ & $1.7-5.8$ & $1.6-3.5$ & $1.9-4.0$ & 3.9 & 4.7 & 4.1 \\
\hline
\end{tabular}

askimmed sample.

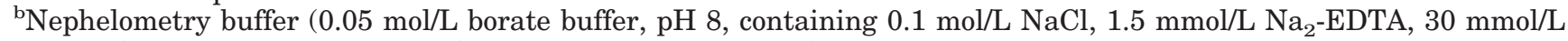
$\mathrm{NaN}_{3}, 2 \mathrm{~g} / \mathrm{L}$ Triton X-100, and $30 \mathrm{~g} / \mathrm{L}$ polyethylene glycol 6000).

${ }^{\mathrm{c} S a l i n e}(0.14 \mathrm{~mol} / \mathrm{L} \mathrm{NaCl})$.

(Marburg, Germany). The specificity of these antisera was assessed by their manufacturers and in some cases verified as previously reported $(18,19)$. Anti- $\beta-\mathrm{CN}$ and anti- $\kappa-\mathrm{CN}$ antisera were antibovine CN. Their obtention, specificity, and reactivity against human $\mathrm{CN}$ have been previously described and debated $(16,17)$.

Polyfunctional hydrophilic microparticles of $300 \pm$ $12 \mathrm{~nm}$ in diameter, synthesized as previously reported (22), and the nephelometry buffer used for the most immunonephelometric assays $(0.05 \mathrm{~mol} / \mathrm{L}$ borate buffer, $\mathrm{pH} 8$ containing $0.1 \mathrm{~mol} / \mathrm{L} \mathrm{NaCl}, 1.5 \mathrm{mmol} / \mathrm{L}$ $\mathrm{Na}_{2}$-EDTA, $30 \mathrm{mmol} / \mathrm{L} \mathrm{NaN}, 2$ g/L Triton X-100 and $30 \mathrm{~g} / \mathrm{L}$ polyethylene glycol 6000 ) were supplied by Sanofi-Diagnostics-Pasteur (Marnes, France). For microparticle-enhanced nephelometric immunoassays, polyfunctional microparticles were covalently coated with whole $\mathrm{CN}, \alpha-\mathrm{LA}, \mathrm{SA}, \mathrm{LF}$, and LZ through the formation of imine bonds between the aldehyde groups on the microparticles and the primary amino groups of the proteins as reported (23).

Human mature milk samples $(n=503)$ used for evaluation studies were collected at home from 18 voluntary lactating mothers from days 15 to 225 postpartum. All these mothers appeared healthy without known disorders, which may affect the milk composition. Milk had been sampled approximately midway through a single feeding, frozen immediately after collection and stored at $-20{ }^{\circ} \mathrm{C}$ until use. They were thawed at $40{ }^{\circ} \mathrm{C}$ in a water bath and vigorously homogeneized, immediately before their analysis.

Procedures For DETERMINATION OF HUMAN MILK PROTEINS

Microparticle-enhanced nephelometric immunoassays were specifically developed for the determi- nation of $\beta-\mathrm{CN}, \kappa-\mathrm{CN}, \alpha-\mathrm{LA}, \mathrm{SA}, \mathrm{LF}$, and $\mathrm{LZ}$ in human milk. Microparticle-enhanced nephelometric immunoassays were performed in a one-step reaction as described in details in Table 1. Unknown diluted whole milk or appropriate serial dilutions of protein standard, microparticle-protein conjugate, and diluted specific antiserum were mixed in a reaction microcuvette (Nephelia microcuvette; Sanofi-Diagnostics-Pasteur) with nephelometry buffer to give a final volume of $300 \mu \mathrm{L}$. All predilutions were performed in the nephelometry buffer with an automated dilutor (Hamilton, Bonaduz, Switzerland). The scattered light was measured with a specially designed nephelometer (Nephelia N600, Sanofi-Diagnostics-Pasteur) (24) equipped with an helium-neon laser (wavelength, $632.8 \mathrm{~nm}$ ). Cubic spline-smoothed calibration curves and unknown sample concentrations were calculated with a microcomputer (MBC 885, Sanyo Electric Co., Tokyo, Japan).

IgA, C3, and C4 determinations were performed by conventional immunonephelometric assays, routinely used in human serum (15) and applied here in milk samples (Table 1). Milk samples were preclarified with 1,1,2-trichlorotrifluoroethane (25) before their dilution. Diluted milk sample or standard, specific antiserum and diluent were mixed together in reaction microcuvette and the scattered light was measured with the Nephelia N600 nephelometer. Samples with high protein concentrations needed to be tested again at higher dilution than indicated in Table 1.

\section{Evaluation study}

Repeatability of the calibration curves was estimated by measuring light scattering for one inter- 
mediate dilution or for each dilution of standard in ten successive assays. The precision of the assays was assessed by measuring human milk samples with intermediate, low, and high concentrations 10 , 12 , or 30 times during the same assay (within-run precision), and on 10 successive assays (between-run precision). Repeatability of the calibrations and precision of the assays were expressed as the coefficient of variation (CV \%).

Recovery studies were carried out in dilutionoverloading assays. The dilution assays were performed on serial dilutions of several milk samples with high protein concentrations. In the overloading experiments, increasing volumes of high concentrated samples (C3 and C4) or increasing amounts of purified proteins (for all others proteins) were added to several milk samples with low protein concentrations. Diluted and overloaded samples were assayed as unknown milk samples. Mean recovery was calculated for each protein and the results of the 133 dilution-overloading assays thus performed were subjected to linear regression analysis (measured $=$ $\mathrm{b}+\mathrm{a}$ theoretical). For each protein, the null hypothesis $\mathrm{H}_{0}$ (intercept $\mathrm{b}=0$ and slope $\mathrm{a}=1$ ) vs the alternative hypothesis $\mathrm{H}_{1}$ (intercept $\mathrm{b} \neq 0$ and slope $a \neq 1$ ) was tested by Fisher (F) and Student's $t$ tests, respectively.

\section{Protein Determinations In HUMAN MATURE MiLK}

Applicability of the microparticle-enhanced nephelometric immunoassays developed for $\beta-\mathrm{CN}$, $\kappa-\mathrm{CN}$, $\alpha-\mathrm{LA}, \mathrm{SA}, \mathrm{LF}$, and LZ was tested on at least 495 mature milk samples. Conventional immunonephelometry was used to measure IgA, C3, and C4 complement fractions in 373 to 495 samples, according to proteins. All these nephelometric immunoassays were performed following the procedures described in Table 1. Version 2.0 of the computer program Prism (Graphpad Software Inc., San Diego, CA) was used for all data analysis and statistics.

\section{Results}

\section{Calibration Ranges}

Decreasing sigmoidal curves were obtained for $\beta-\mathrm{CN}, \kappa-\mathrm{CN}, \alpha-\mathrm{LA}, \mathrm{SA}, \mathrm{LF}$, and LZ determinations, performed by microparticle-enhanced nephelometric immunoassays, and increasing calibration curves were observed in uncompetitive conventional immunonephelometry for the measurement of IgA, C3, and $\mathrm{C} 4$ complement fractions. Calibrations ranges and repeatability of the standardizations are given Table 1 . The lower limits of each calibration range corresponded to protein concentrations giving light scattering intensity significantly different (3 SD at least) from the light scattered observed in the absence of protein to be measured. The upper limits were protein concentrations giving light scattered significantly different (3 SD at least) from the light scattered by dispersed microparticle-protein conju- gate alone (microparticle-enhanced nephelometric immunoassays), or from the light scattered observed at the equivalence zone (conventional immunonephelometric assays).

\section{Evaluation STUdy}

Table 2 shows the within-run and between-run precision results. The coefficients of variation calculated for large distributions of milk protein concentration ranged between $1.0 \%$ and $10.9 \%$ for the within-run and between $0.9 \%$ and $13.8 \%$ for the between-run studies. In 32 cases from these 48 coefficients of variation obtained, they were lower than $5 \%$.

All the analytical recovery results are reported in Table 3. Mean recoveries were comprised between $92 \%$ to $104 \%$ for all nine proteins. Statistical studies of the parameters of the linear regression (measured $=\mathrm{b}+\mathrm{a}$ theoretical), performed for each protein over the large concentration range investigated, indicated that the intercepts (b) and the slopes (a) were never significantly different $(p>$ 0.05 ) from 0 and 1 , respectively.

\section{ApPlication to HUMAN MATURE MILK}

Protein concentrations measured in mature milk samples are plotted in Figure 1 as boxes extending from the 25 th percentile to the 75 th percentile, with a horizontal line at the median, and whiskers extending down to the smallest value and up to the largest.

\section{Discussion}

Conventional immunonephelometry is commonly used to assay proteins in human serum (15). In our work, it allows the measurement of IgA, C3, and C4 complement fractions in human mature milk with precision and accuracy. However, conventional immunonephelometry has two drawbacks: its sensibility ( $1 \mathrm{mg} / \mathrm{L}$ ) constrains to test milk samples at weak dilution (1/300 for IgA and 1/30 for C3 and C4 in the reaction mixture) and thus requires their clarification by pretreatment; in other hand, as in all immunoassays based on an uncompetitive reaction, samples with high protein concentrations should be reassayed at higher dilution to avoid a risk of under-estimation by antigen excess.

Microparticle-enhanced nephelometric immunoassays are based on the nephelometric quantification of the inhibition of microparticle-protein conjugates immunoagglutination by the free proteins to be assayed (23). Such immunoassays have been previously described as sensitive and accurate techniques for the measurement of numerous human serum proteins (26) and of the main proteins of bovine milk (27). The microparticle-enhanced nephelometric immunoassays especially developed for the measurement of $\beta-\mathrm{CN}$, к-CN, $\alpha-\mathrm{LA}, \mathrm{SA}, \mathrm{LF}$, and LZ in human milk preserves the advantages of 
TABLE 2

Precision of Protein Determinations

\begin{tabular}{|c|c|c|c|c|c|c|c|}
\hline \multirow[b]{2}{*}{ Protein ${ }^{a}$} & \multicolumn{4}{|c|}{ Within-run precision } & \multicolumn{3}{|c|}{ Between-run precision $^{b}$} \\
\hline & $n$ & Mean $(\mathrm{g} / \mathrm{L})$ & $\mathrm{SD}(\mathrm{g} / \mathrm{L})$ & $\mathrm{CV}(\%)$ & Mean $(\mathrm{g} / \mathrm{L})$ & $\mathrm{SD}(\mathrm{g} / \mathrm{L})$ & $\mathrm{CV}(\%)$ \\
\hline \multirow[t]{3}{*}{$\beta-\mathrm{CN}$} & 30 & 0.83 & 0.09 & 10.9 & 1.13 & 0.14 & 12.2 \\
\hline & 30 & 3.85 & 0.22 & 5.6 & 4.50 & 0.22 & 5.0 \\
\hline & 30 & 10.26 & 0.35 & 3.4 & 11.04 & 0.56 & 5.1 \\
\hline \multirow[t]{3}{*}{ к-CN } & 30 & 0.47 & 0.03 & 7.2 & 0.46 & 0.05 & 9.9 \\
\hline & 30 & 1.29 & 0.04 & 3.0 & 1.39 & 0.05 & 3.2 \\
\hline & 30 & 2.97 & 0.07 & 2.4 & 2.87 & 0.11 & 3.9 \\
\hline \multirow[t]{3}{*}{$\alpha-\mathrm{LA}$} & 30 & 1.52 & 0.07 & 4.6 & 1.36 & 0.09 & 6.7 \\
\hline & 30 & 3.45 & 0.04 & 1.0 & 4.09 & 0.12 & 2.8 \\
\hline & 30 & 9.74 & 0.20 & 2.0 & 12.08 & 0.26 & 2.2 \\
\hline SA & 10 & 0.51 & 0.03 & 5.1 & 0.52 & 0.04 & 6.8 \\
\hline \multirow[t]{3}{*}{$\mathrm{LF}$} & 30 & 1.82 & 0.09 & 4.8 & 1.29 & 0.08 & 5.9 \\
\hline & 30 & 3.07 & 0.10 & 3.3 & 3.00 & 0.11 & 3.8 \\
\hline & 30 & 6.69 & 0.25 & 3.8 & 7.10 & 0.25 & 3.5 \\
\hline \multirow[t]{3}{*}{ LZ } & 30 & 0.24 & 0.01 & 2.4 & 0.24 & 0.01 & 4.8 \\
\hline & 30 & 0.34 & 0.01 & 3.1 & 0.35 & 0.02 & 4.5 \\
\hline & 30 & 0.65 & 0.01 & 1.4 & 0.62 & 0.01 & 0.9 \\
\hline \multirow[t]{2}{*}{$\operatorname{IgA}$} & 10 & 0.39 & 0.03 & 6.9 & 0.41 & 0.03 & 8.5 \\
\hline & 10 & 3.08 & 0.09 & 2.9 & 3.11 & 0.12 & 3.8 \\
\hline \multirow[t]{3}{*}{ C3 } & 12 & 0.030 & 0.001 & 2.9 & 0.024 & 0.002 & 8.7 \\
\hline & 12 & 0.075 & 0.002 & 2.2 & 0.046 & 0.003 & 5.8 \\
\hline & 12 & 0.239 & 0.010 & 4.2 & 0.197 & 0.009 & 4.7 \\
\hline \multirow[t]{3}{*}{$\mathrm{C} 4$} & 12 & 0.030 & 0.001 & 3.7 & 0.016 & 0.002 & 13.8 \\
\hline & 12 & 0.077 & 0.002 & 2.1 & 0.072 & 0.003 & 3.9 \\
\hline & 12 & 0.181 & 0.007 & 3.7 & 0.160 & 0.006 & 4.0 \\
\hline
\end{tabular}

${ }^{a}$ Beta-casein $(\beta-\mathrm{CN})$, kappa-casein $(\kappa-\mathrm{CN})$, alpha-lactalbumin $(\alpha-\mathrm{LA})$, serum albumin (SA), lactoferrin (LF), lysozyme (LZ), immunoglobulins A (IgA), C3 and C4 complement fractions; ${ }^{\mathrm{b}} n=10$

conventional immunonephelometry but cancels these drawbacks. Microparticle-enhanced nephelometric immunoassay is an easy-to-perform method and a rapid (30 to $60 \mathrm{~min}$ ), fully automatable one step assay, which is suitable for the measurement of a great number of samples (360 per hour). It is a highly sensitive assay $(1 \mu \mathrm{g} / \mathrm{L})$ allowing a great dilution of milk samples (1/3000 to $1 / 150000$ in the reaction mixture). Such dilutions removes any interference due to milk sample turbidity and sample clarification. Furthermore, underestimation of the highest protein concentrations is avoided by the inhibition mode used.

Calibration ranges obtained for the nine proteins assayed in this work by conventional or microparticle-enhanced immunonephelometry allowed the measurement of these proteins in human milk. The good repeatability of calibration curves (between $1 \%$ and $6 \%$ ) could allow to consider the use of a singlepoint control to recalibrate a late multi-point standard curve. Precision studies indicated that these assay ranges were covered with reliability $(\mathrm{CVs}$

TABLE 3

Analytical Recovery

\begin{tabular}{|c|c|c|c|c|c|c|c|}
\hline \multirow[b]{2}{*}{ Protein $^{a}$} & \multirow{2}{*}{$\begin{array}{l}\text { Range investigated } \\
(\mathrm{g} / \mathrm{L})\end{array}$} & \multirow[b]{2}{*}{$n$} & \multicolumn{2}{|c|}{ Recovery (\%) } & \multicolumn{3}{|c|}{$\begin{array}{c}\text { Linear regression (measured }=\mathrm{b} \\
+\mathrm{a} \text { theoretical) }\end{array}$} \\
\hline & & & Mean & SD & b (g/L) & $\mathrm{a}$ & $r$ \\
\hline$\beta-\mathrm{CN}$ & $0.8-13.8$ & 16 & 101 & 7 & $-0.279^{\mathrm{b}}$ & $1.098^{\mathrm{c}}$ & 0.987 \\
\hline к-CN & $0.6-4.4$ & 12 & 99 & 8 & $-0.130^{\mathrm{b}}$ & $1.060^{\mathrm{c}}$ & 0.996 \\
\hline$\alpha-\mathrm{LA}$ & $0.6-14.1$ & 13 & 99 & 7 & $0.003^{b}$ & $0.990^{\mathrm{c}}$ & 0.997 \\
\hline SA & $0.2-2.7$ & 13 & 104 & 7 & $0.021^{\mathrm{b}}$ & $1.005^{\mathrm{c}}$ & 0.999 \\
\hline $\mathrm{LF}$ & $0.8-11.4$ & 18 & 97 & 11 & $-0.244^{\mathrm{b}}$ & $1.097^{\mathrm{c}}$ & 0.992 \\
\hline LZ & $0.1-1.0$ & 16 & 101 & 10 & $0.013^{\mathrm{b}}$ & $0.960^{\mathrm{c}}$ & 0.994 \\
\hline $\operatorname{IgA}$ & $0.3-5.2$ & 13 & 100 & 5 & $-0.004^{\mathrm{b}}$ & $1.013^{\mathrm{c}}$ & 0.998 \\
\hline C3 & $0.021-0.335$ & 16 & 99 & 4 & $-0.001^{b}$ & $1.016^{\mathrm{c}}$ & 0.998 \\
\hline $\mathrm{C} 4$ & $0.019-0.115$ & 16 & 92 & 9 & $-0.004^{b}$ & $1.021^{\mathrm{c}}$ & 0.993 \\
\hline
\end{tabular}

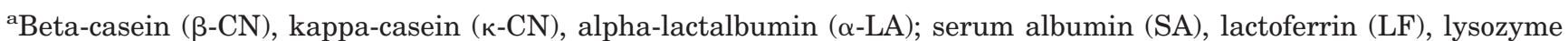
(LZ), immunoglobulins A (IgA), C3, and C4 complement fractions; b not significantly different $(p>0.05)$ from $0(F$ test for $\mathrm{b}=0$ vs $\mathrm{b} \neq 0)$; ${ }^{\mathrm{c}}$ not significantly different $(p>0.05)$ from $1(t$-test for $\mathrm{a}=1$ vs $\mathrm{a} \neq 1)$. 

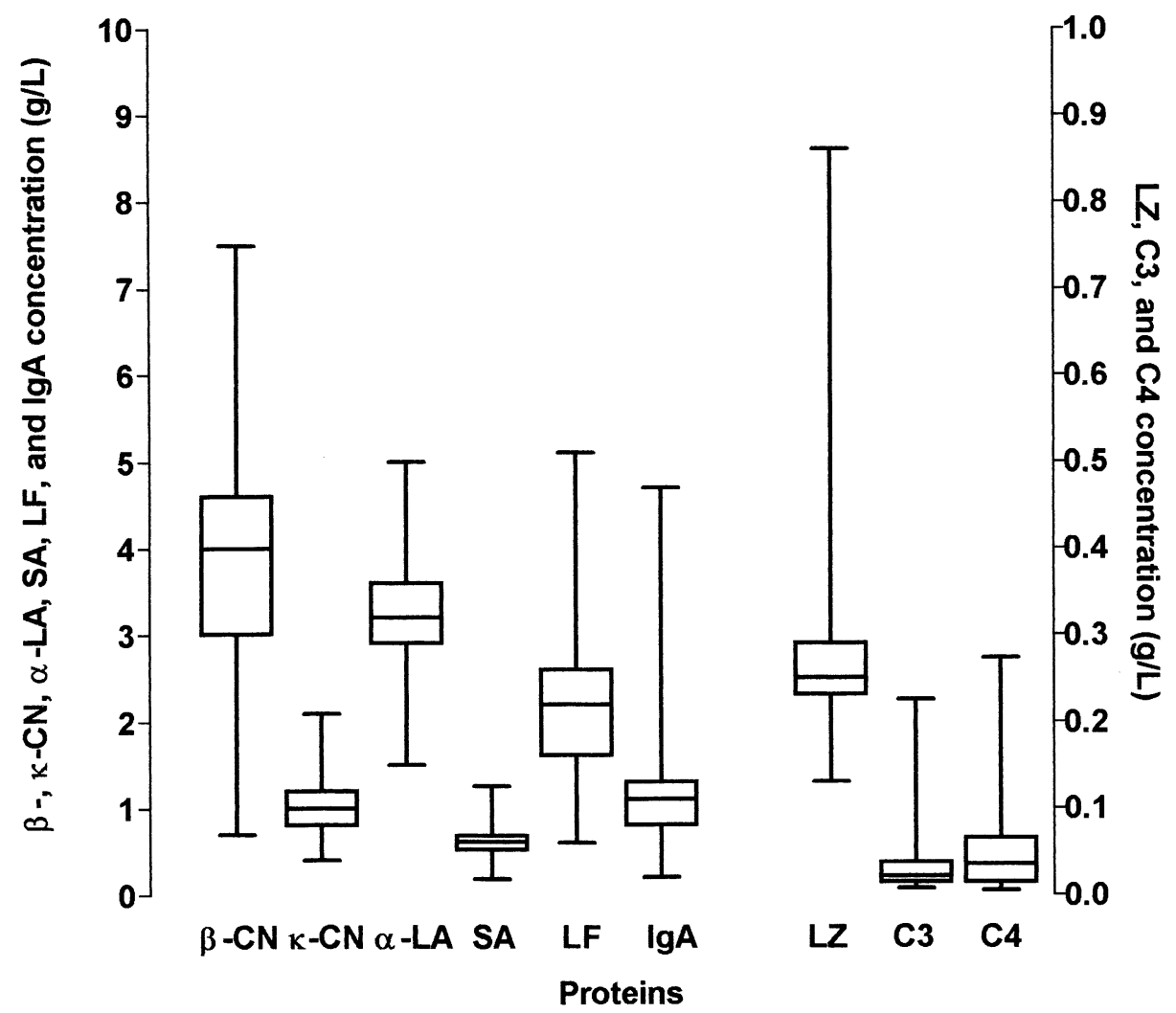

Figure 1 - Protein profile of human mature milk: results are plotted as box extending from the 25th percentile to the 75 th percentile, with a horizontal line at the median, and whiskers extended down to the smallest value and up to the largest. Beta-casein ( $\beta$-CN), $n=499$; kappa-casein (к-CN), $n=500$; alpha-lactalbumin ( $\alpha$-LA), $n=503$; serum albumin (SA), $n=$ 501; lactoferrin (LF), $n=497$; immunoglobulins A (IgA), $n=495$; lysozyme (LZ), $n=495$; C3 $(n=389)$ and C4 ( $n=373$ ) complement fractions.

often lower than 5\%, in within- and between-run). Recovery studies showed close agreement between the theoretical and measured protein concentrations in dilution-overloadind assays (linear recovery on large ranges of concentrations with mean percentage very close to 100\%). Results of the measurements of nine proteins performed together in a great number of human mature milk samples are, for the most part, in good agreement with those previously reported in past years (2-14), using different techniques and, the most often, restricted to the determination of the one or another of these proteins.

Emergence of new analytical procedures in the late years, such as conventional or microparticleenhanced immunonephelometry, today allows major proteins of human milk to be analyzed with sensitivity, easiness, and singleness of methodologies. This technically homogeneous approach leads to the assessment of a protein profile of mature human milk such as shown Figure 1. Human milk protein profiles could carry a better knowledge of the normal lactogenesis and a re-evaluation of the nutritious and immunological functions of human milk. They could display the immaturity of preterm milks (28), the increase of IgA, LZ, and LF in milk from mothers with infections such as mastitis (29), and the changes in milk proteins composition occuring in metabolic disorders (30) or with some medications and drugs such as nicotine that influence prolactine or oxytocin levels $(31,32)$. Human milk protein profiles could be also usable to better evaluate nursery milk bank products and to improve individual fortification.

\section{Acknowledgements}

We are grateful to all the benevolent mothers who took some time to put aside some of their own milk for research purposes. P. Montagne is research engineer at the Institut National de la Santé et de la Recherche Médicale. M.L. Cuillière is study engineer at the Centre National de la Recherche Scientifique.

\section{References}

1. Jensen RG. Handbook of Milk Composition. San Diego: Academic Press, 1995.

2. Kunz C, Lönnerdal B. Casein and casein subunits in preterm milk, colostrum, and mature human milk. $J$ Pediatr Gastr Nutr 1990; 10: 454-61.

3. Ekstrand B, Bjorck L. Fast protein liquid chromatography of antibacteril components in milk: lactoperoxydase, lactoferrin and lysozyme. $J$ Chromatogr 1986; 358: 429-33.

4. Nagasawa T, Kiyosawa I, Fokuwatari Y, Hitayama T. 
Alpha-lactalbumin and serum albumin in human milk. J Dairy Sci 1973; 56: 177-80.

5. Sanchez-Pozo A, Lopez J, Pita ML, et al. Changes in the protein fractions of human milk during lactation. Ann Nutr Metab 1986; 30: 15-20.

6. Kunz C, Lönnerdal B. Human-milk proteins : analysis of casein and casein subunits by anion-exchange chromatography, gel electrophoresis, and specific staining methods. Am J Clin Nutr 1990; 51: 37-46.

7. Younes B, Al-Hakeem A, Al Shammary F, Imambaccus Y. Breast milk lysozyme concentration in relation to age, period of lactation and parity of mothers. Med Sci Res 1994; 22: 323-4.

8. Goldman AS, Garza C, Johnson CA, Nichols BL, Goldblum RM. Immunologic factors in human milk during the first year of lactation. J Pediatr 1982; 100: 563-7.

9. Hennard PF, Brasseur DJ, Delogne-Desnoeck JB, Dramaix MM, Robyn CE. Lysozyme, lactoferrin, and secretory immunoglobulin A content in breast milk: influence of duration of lactation, nutrition status, prolactin status, and parity of the mother. Am J Clin Nutr 1991; 53: 32-9.

10. Hirai Y, Kawakata N, Satoh K, et al. Concentrations of lactoferrin and iron in human milk at different stages of lactation. J Nutr Sci Vitaminol 1990; 36: 531-44.

11. Lönnerdal B, Forsum E, Grebe-Medhin M, Hambraeus L. Breast milk composition in ethiopan and swedish mothers: lactose, nitrogen, and protein contents. Am J Clin Nutr 1976; 29: 1134-41.

12. Chtourou A, Brignon G, Ribadeau-Dumas B. Quantification of $\beta$-casein in human milk. J Dairy Res 1985; 52: $239-47$.

13. Forsum E. Determination of alpha-lactalbumin in human milk. J Dairy Sci 1976; 59: 14-8.

14. Broxmeyer HE, Bicknel DC, Gillis S, Harris EL, Pelus LM, Sledge GW. Lactoferrin: affinity purification from human milk and polymorphonuclear neutrophils using monoclonal antibody (II2C) to human lactoferrin, development of an immunoradiometric assay using II2C, and myelopoietic regulation and receptor-binding characteristics. Blood Cells 1986; 11: 429-46.

15. Sieber A, Gross J. Determination of proteins by laser nephelometry. Laboratoriumsblätter 1976; 26: 11723.

16. Cuillière $\mathrm{ML}$, Molé $\mathrm{C}$, Montagne $\mathrm{P}$, Béné MC, Faure G. Measurement of beta-casein in human milk by microparticle-enhanced nephelometric immunoassay. Food Agric Immunol 1997; 9: 185-92.

17. Cuillière ML, Trégoat V, Béné MC, Faure G, Montagne $P$. Changes in the $\kappa$-casein and $\beta$-casein concentrations in human milk during lactation. J Clin Lab Anal 1999; 13: 213-8.

18. Cuillière ML, Abbadi M, Molé C, Montagne $\mathrm{P}$, Béné MC, Faure G. Microparticle-enhanced nephelometric immunoassay of alpha-lactalbumin in human milk. J Immunoassay 1997; 18: 97-109.

19. Cuillière ML, Montagne $\mathrm{P}$, Molé $\mathrm{C}$, Béné MC, Faure G. Microparticle-enhanced nephelometric immunoassay of lactoferrin in human milk. J Clin Lab Anal 1997; 11: 239-43.

20. Montagne $\mathrm{P}$, Cuillière ML, Molé C, Béné MC, Faure G. Microparticle-enhanced nephelometric immunoassay of lysozyme in milk and other human body fluids. Clin Chem 1998; 44: 1610-5.

21. Tregoat $\mathrm{V}$, Montagne $\mathrm{P}$, Cuillière $\mathrm{ML}$, Béné $\mathrm{MC}$, Faure G. C3/C4 concentration ratio reverses between colostrum and mature milk in human lactation. J Clin Immunol 1999; 19: 300-4.

22. Marchand J, Varcin P, Riochet D, et al. Synthesis of new hydrophilic microspheres: optimized carriers for microparticle-enhanced nephelometric immunoassay. Biopolymers 1992; 32: 971-80.

23. Montagne $\mathrm{P}$, Varcin $\mathrm{P}$, Cuillière $\mathrm{ML}$, Duheille J. Microparticle-enhanced nephelometric immunoassay with microsphere-antigen conjugates. Bioconjugate Chem 1992; 3: 187-93.

24. Cuillière ML, Montagne $\mathrm{P}$, Bessou T, et al. Microparticle-enhanced nephelometric immunoassay (Néphélia $\left.{ }^{\circledR}\right)$ for immunoglobulins G, A, and M. Clin Chem 1991; 37: 20-5.

25. Voigt HW. Klärung lipämischer seren durch neues verfahren. Laboratoriumsblätter 1977; 27: 168-72.

26. Montagne $\mathrm{P}$, Laroche $\mathrm{P}$, Bessou $\mathrm{T}$, Cuillière $\mathrm{ML}$, Varcin P, Duheille J. Measurement of eleven serum proteins by microparticle-enhanced nephelometric immunoassay. J Clin Chem Clin Biochem 1992; 30: 217-22.

27. Montagne $\mathrm{P}$, Cuillière ML, Marchal E, et al. Application of microparticle-enhanced nephelometric immunoassay of alpha-, beta- and kappa-caseins to evaluate quality of milk, from the production to the valorization in cheese industry. Lait 1995; 75: 221-37.

28. Montagne $\mathrm{P}$, Cuillière ML, Molé C, Béné MC, Faure G. Immunological and nutritional composition of human milk in relation to prematurity and mothers' parity during the first 2 weeks of lactation. J Pediatr Gastroenterol Nutr 1999; 29: 75-80.

29. Prentice A, Prentice AM, Lamb WH. Mastitis in rural Gambian mothers and the protection of the breast by milk antimicrobial factors. Trans $R$ Soc Trop Med Hyg 1985; 70: $90-5$.

30. Neubauer SH, Ferris AM, Chase CG, et al. Delayed lactogenesis in women with insulin-dependent diabetes mellitus. Am J Clin Nutr 1993; 58: 54-60.

31. Andersen AN, Lund-Andersen C, Larsen JF, et al. Suppressed prolactin but normal neurophysin levels in cigarette smoking breast-feeding women. Clin Endocrinol 1982; 17: 363-8.

32. Anderson PO. Drug use during breast-feeding. Clin Pharmacokinet 1991; 10: 594-624. 